\title{
Association of cytochrome P-450I7 (T-34C) polymorphism and the risk of acne vulgaris: a meta-analysis
}

\author{
Zależność między polimorfizmem (T-34C) cytochromu P-450I7 a ryzykiem \\ występowania trądziku pospolitego - metaanaliza
}

\author{
Mazaher Ramezani', Elisa Zavattaro², Masoud Sadeghi ${ }^{3,4}$ \\ IMolecular Pathology Research Centre, Imam Reza Hospital, Kermanshah University of Medical Sciences, Kermanshah, Iran \\ 2Dermatology Unit, Department of Translational Medicine, University of Eastern Piedmont "Amedeo Avogadro", Novara, Italy \\ 3Medical Biology Research Centre, Kermanshah University of Medical Sciences, Kermanshah, Iran \\ ${ }^{4}$ Students Research Committee, Kermanshah University of Medical Sciences, Kermanshah, Iran
}

Dermatol Rev/Przegl Dermatol 2019, 106, 591-602 DOI: https://doi.org/10.5। |4/dr.2019.92732

CORRESPONDING AUTHOR/ ADRES DO KORESPONDENCJI: Masoud Sadeghi MSc Medical Biology Research Centre Students Research Committee Kermanshah University of Medical Sciences 6714415185 Kermanshah, Iran phone: +989185960644 e- mail: sadeghi_mbrc@yahoo.com

\section{ABSTRACT}

Objective: A meta-analysis evaluated the association of cytochrome P-45017 (CYP17) T-34C polymorphism with the risk of acne.

Material and methods: The databases (Scopus, Web of Science, PubMed, and Cochrane Library) were searched until September 2018.

Results: Out of 4 studies included in the meta-analysis, the odds ratio of $\mathrm{C}$ versus $\mathrm{T}$ in the patients compared to the controls was $1.42(p=0.02)$, in CC vs. TT it was $1.54(p=0.04)$, in TC vs. TT it was $1.46(p=0.12)$, in TC + CC vs. TT it was $1.55(p=0.04)$, and in CC vs. TT + TC it was $1.39(p=0.06)$. There was no acne risk related to CYP17 (T-34C) in any of the genetic models in Caucasian ethnicity, whereas in Asian ethnicity there was higher acne risk related to CYP17 (T-34C).

Conclusions: The results of the present meta-analysis showed that the presence of $C$ allele and CC genotype of CYP17 polymorphism can be risk factors for acne, mainly in Asian ethnicity.

\section{STRESZCZENIE}

Cel: $W$ ramach metaanalizy oceniano zależność między obecnością polimorfizmu T-34C cytochromu P-45017 (CYP17) a ryzykiem występowania trądziku.

Materiał i metody: Przeszukano naukowe bazy danych Scopus, Web of Science, PubMed i Cochrane Library do września 2018 roku.

Wyniki: W 4 badaniach włączonych do metaanalizy iloraz szans (OR) $\mathrm{C}$ vs $\mathrm{T}$ u pacjentów $\mathrm{w}$ porównaniu $\mathrm{z}$ grupą kontrolną wyniósł 1,42 $(p=0,02)$; CC vs TT $1,54(p=0,04) ;$ TC vs TT $1,46(p=0,12) ;$ TC + CC vs TT $1,55(p=0,04)$ oraz CC vs TT + TC $1,39(p=0,06)$. Nie stwierdzono zależności między ryzykiem wystąpienia trądziku a polimorfizmem (T-34C) CYP17 w żadnym $\mathrm{z}$ modeli genetycznych u osób pochodzenia kaukaskiego, natomiast u osób pochodzenia azjatyckiego wykazano podwyższone ryzyko wystąpienia trądziku związane z obecnością polimorfizmu (T-34C) CYP17.

Wnioski: Wyniki przeprowadzonej metaanalizy wykazują, że obecność allela C oraz genotypu CC polimorfizmu CYP17 może stanowić czynnik ryzyka występowania trądziku, głównie u osób pochodzenia azjatyckiego.

Key words: acne, polymorphism, genetics, CYP17, ethnicity.

Słowa kluczowe: trądzik, polimorfizm, genetyka, CYP17, pochodzenie etniczne. 


\section{INTRODUCTION}

Acne vulgaris is one of the most common skin diseases, affecting about $85 \%$ of adolescents in Western countries [1, 2]. The pathogenesis of this disease is multiple and complex and is still not well defined, but genetic relationships have been documented [3]. The share of genetic factors in the development of this disease has been postulated for a long time, which is supported by genealogical research and the study of twins $[4,5]$; however, to date, only a few data have been reported in the literature [6]. The key role of the disease is attributed to hormonal disorders that cause sebaceous hypertrophy, abnormal keratosis, and the presence of Cutibacterium acnes [7]. Cytochrome P-450 (CYP) comprises multiple families of iron-containing haemoproteins that catalyse the metabolism of endoand exogenous products such as fatty acids, steroids, and a number of hormones and vitamins [8,9]. The cytochrome P-45017 (CYP17) gene is located on chromosome 10q24.3, coding for P450c17, which is one of the key enzymes in the androgen biosynthesis and a mediator of $17 \alpha$-hydroxylase and 17, 20-lyase activity [10]. The existence of a T > C (T-34C) small nucleotide polymorphism (SNP) in nucleotide 27 has been reported in the promoter of the CYP17 gene and related to breast cancer risk $[11,12]$. In addition to the investigation of this gene in acne $[6,8,13,14]$, its association between CYP17 with Down syndrome and Alzheimer's disease [15], and prostate cancer [16] has also been studied.

\section{OBJECTIVE}

Herein, the association of CYP17 (T-34C) polymorphism (rs743572) related to the risk of acne was evaluated in a meta-analysis study.

\section{MATERIAL AND METHODS}

The study was designed according to the instructions of the Preferred Reporting Items for Systematic Reviews and Meta-Analyses (PRISMA) [17].

\section{Literature search strategy}

Four databases including Scopus, Web of Science, PubMed, and the Cochrane Library were investigated for studies published until September 2018, with no language restriction, using the terms "CYP17", "Cytochrome P450 17A1", "CYP17A1", or "CYP" and ("Acne").

\section{Eligibility criteria}

M.S., as the first reviewer, searched the articles among the databases and checked their titles and

\section{WPROWADZENIE}

Trądzik pospolity (acne vulgaris) należy do najczęstszych schorzeń skóry. Występuje u ok. 85\% młodzieży w krajach zachodnich [1, 2]. Patogeneza choroby jest złożona, wieloczynnikowa i nadal niedostatecznie poznana, choć potwierdzono rolę uwarunkowań genetycznych w jej rozwoju [3]. Znaczenie czynników o podłożu genetycznym jest postulowane już od długiego czasu. Twierdzenia te zostały poparte analizami genealogicznymi oraz badaniami z udziałem bliźniąt [4, 5], jednak dane dostępne w piśmiennictwie są bardzo ograniczone [6]. Uważa się, że istotną rolę w rozwoju trądziku pospolitego odgrywają zaburzenia hormonalne powodujące przerost gruczołów łojowych i nieprawidłowe rogowacenie, a także obecność bakterii z gatunku Cutibacterium acnes [7]. Cytochrom P-450 (CYP) należy do licznej rodziny hemoprotein zawierających żelazo, które katalizują metabolizm substancji endoi egzogennych, takich jak kwasy tłuszczowe i steroidy, a także szereg hormonów i witamin [8, 9]. Gen (CYP17) cytochromu P-45017 jest położony na chromosomie 10q24.3 i koduje białko P450c17 będące jednym z kluczowych enzymów w biosyntezie androgenów oraz mediatorem aktywności 17a-hydroksylazy i 17,20-liazy [10]. W piśmiennictwie opisywano obecność polimorfizmu pojedynczego nukleotydu (SNP) T>C (T-34C) w nukleotydzie 27 promotora genu CYP17, wskazując na jego powiązanie z ryzykiem rozwoju raka piersi [11, 12]. Oprócz roli tego genu w trądziku $[6,8,13,14]$ badano także zależność między CYP17 a zespołem Downa i chorobą Alzheimera [15] oraz rakiem gruczołu krokowego [16].

\section{CEL}

W przedstawionej metaanalizie poddano ocenie zależność między obecnością polimorfizmu (T-34C) CYP17 (rs743572) a ryzykiem występowania trądziku.

\section{MATERIAŁ I METODY}

Zastosowano metodologię zgodną z zaleceniami zawartymi w deklaracji dotyczącej prawidłowego raportowania przeglądów systematycznych i metaanaliz (PRISMA) [17].

\section{Strategia przeglądu piśmiennictwa}

Przeszukano cztery naukowe bazy danych: Scopus, Web of Science, PubMed i Cochrane Library, pod kątem badań opublikowanych do września 2018 roku. Zastosowano następujące słowa kluczowe: "CYP17”, „cytochrom P450 17A1”, „CYP17A1” lub "CYP" oraz "trądzik", bez ograniczeń językowych. 
abstracts, and if they were not relevant, they were deleted. Subsequently, the full texts of the relevant studies were checked based on the eligibility criteria. The second reviewer (M.R.) re-assessed the full texts. The inclusion criteria were the case-control studies evaluating genotype distributions of CYP17 (T-34C) polymorphism in acne patients using the odds ratio (OR) and 95\% confidence intervals (95\% CIs). The exclusion criteria were animal studies, review articles, meeting abstracts, letter to editors, studies without a control group, and family-based studies.

\section{Data extraction}

Two reviewers (E.Z., \& M.S.) independently extracted the data. The data extracted from each study are shown in table 1 .

\section{Quality assessment}

M.R. assessed the quality of each case-control study using a questionnaire of the Newcastle-Ottawa Quality Assessment Scale (NOS) [18].

\section{Statistical analysis}

We used Review Manager 5.3 software to analyse the data using OR and 95\% CI to check the relationship between acne risk and CYP17 (T-34C) polymorphism and the impact of this polymorphism on the severity of acne. Five genetic models were used to show this correlation [19]. $P$-value $<0.05$ showed a significant relationship. The Cochrane $Q$ test and $I^{2}$ statistic were used to estimate heterogeneity across the

\section{Kryteria doboru}

Pierwszy badacz (M.S.) przeszukał publikacje dostępne w bazach danych, sprawdzajac ich tytuły i streszczenia. Brak związku z tematem metaanalizy powodował ich odrzucenie. Następnie odpowiednie publikacje zostały zweryfikowane w pełnej wersji tekstowej na podstawie przyjętych kryteriów doboru do metaanalizy. Drugi badacz (M.R.) przeprowadził ponowną ocenę prac w wersji pełnotekstowej. Kryteria włączenia obejmowały: badania kliniczno-kontrolne oceniające rozkład genotypowy polimorfizmu (T-34C) CYP17 u chorych na trądzik przy użyciu ilorazu szans (OR) i 95-procentowego przedziału ufności (95\% CI). Przyjęto również następujące kryteria wyłączenia: badania na zwierzętach, artykuły przeglądowe, streszczenia ze spotkań naukowych, listy do redakcji, badania bez grupy kontrolnej oraz badania rodzinne.

\section{Ekstrakcja danych}

Niezależną ekstrakcję danych przeprowadziło dwóch badaczy (E.Z. oraz M.S.). Dane wyekstrahowane z poszczególnych badań przedstawiono w tabeli 1 .

\section{Ocena jakości}

M.R. dokonał oceny jakości poszczególnych badań kliniczno-kontrolnych przy wykorzystaniu kwestionariusza oceny jakości w skali Newcastle-Ottawa (NOS) [18].

Table I. Characteristics of the studies included in the meta-analysis $(n=4)$

Tabela I. Charakterystyka badań włączonych do metaanalizy $(n=4)$

\begin{tabular}{|c|c|c|c|c|c|c|c|c|c|c|c|c|}
\hline \multirow[t]{2}{*}{$\begin{array}{l}\text { Study/ } \\
\text { Badanie }\end{array}$} & \multirow[t]{2}{*}{$\begin{array}{c}\text { Study } \\
\text { population/ } \\
\text { Grupa badana }\end{array}$} & \multirow{2}{*}{$\begin{array}{l}\text { Source of } \\
\text { controls/ } \\
\text { Pocho- } \\
\text { dzenie } \\
\text { grupy } \\
\text { kontrolnej }\end{array}$} & \multirow{2}{*}{$\begin{array}{c}\text { Sample } \\
\text { size } \\
\text { (Case: } \\
\text { Control)/ } \\
\text { Wielkość } \\
\text { próby } \\
\text { (grupa } \\
\text { badana: } \\
\text { grupa } \\
\text { kontrolna) }\end{array}$} & \multicolumn{3}{|c|}{ Acne/Trądzik } & \multicolumn{3}{|c|}{$\begin{array}{l}\text { Control/ } \\
\text { Grupa } \\
\text { kontrolna }\end{array}$} & \multirow{2}{*}{$\begin{array}{c}\text { Genotyping } \\
\text { method/ } \\
\text { Metoda } \\
\text { genotypowania }\end{array}$} & \multirow{2}{*}{$\begin{array}{l}\text { P-value for HWE } \\
\text { in controls/ } \\
\text { Wartośćp } \\
\text { dla HWE } \\
\text { w grupach } \\
\text { kontrolnych }\end{array}$} & \multirow[t]{2}{*}{$\begin{array}{l}\text { Score*I } \\
\text { Wynik* }\end{array}$} \\
\hline & & & & $\overline{T T}$ & TC & $\mathrm{CC}$ & $\mathrm{TT}$ & TC & $\overline{C C}$ & & & \\
\hline $\mathrm{He}, 2006$ [8] & China/Chiny & $\mathrm{HB}$ & 206: 200 & 45 & 103 & 58 & 59 & 99 & 42 & PCR & 0.968 & 7 \\
\hline $\begin{array}{l}\text { Tian, } 2010 \\
{[13]}\end{array}$ & China/Chiny & PB & $79: 39$ & 20 & 30 & 29 & 11 & 18 & 10 & PCR & 0.633 & 8 \\
\hline $\begin{array}{l}\text { Sobjanek, } \\
2015 \text { [6] }\end{array}$ & Poland/Polska & HP & 115:94 & 40 & 53 & 22 & 34 & 43 & 17 & PCR-RFLP & 0.599 & 6 \\
\hline $\begin{array}{l}\text { Chamaie- } \\
\text { Nejad, } 2018 \\
{[14]}\end{array}$ & Iran//ran & $\mathrm{HP}$ & 198: 195 & 132 & 66 & 0 & 164 & 31 & 0 & PCR-RFLP & 0.227 & 8 \\
\hline
\end{tabular}

HB - hospital-based, PB - population-based, HWE - Hardy-Weinberg equilibrium, PCR - polymerase chain reaction, RFLP - restriction fragment length polymorphism. *Quality score according to Newcastle-Ottawa Quality Assessment Scale (NOS).

HB - szpitalna, PB - populacyjna, HWE - równowaga Hardy'ego-Weinberga, PCR - reakcja łańcuchowa polimerazy, RFLP - polimorfizm długości fragmentów restrykcyjnych. *Ocena jakości według skali Newcastle-Ottawa (NOS). 


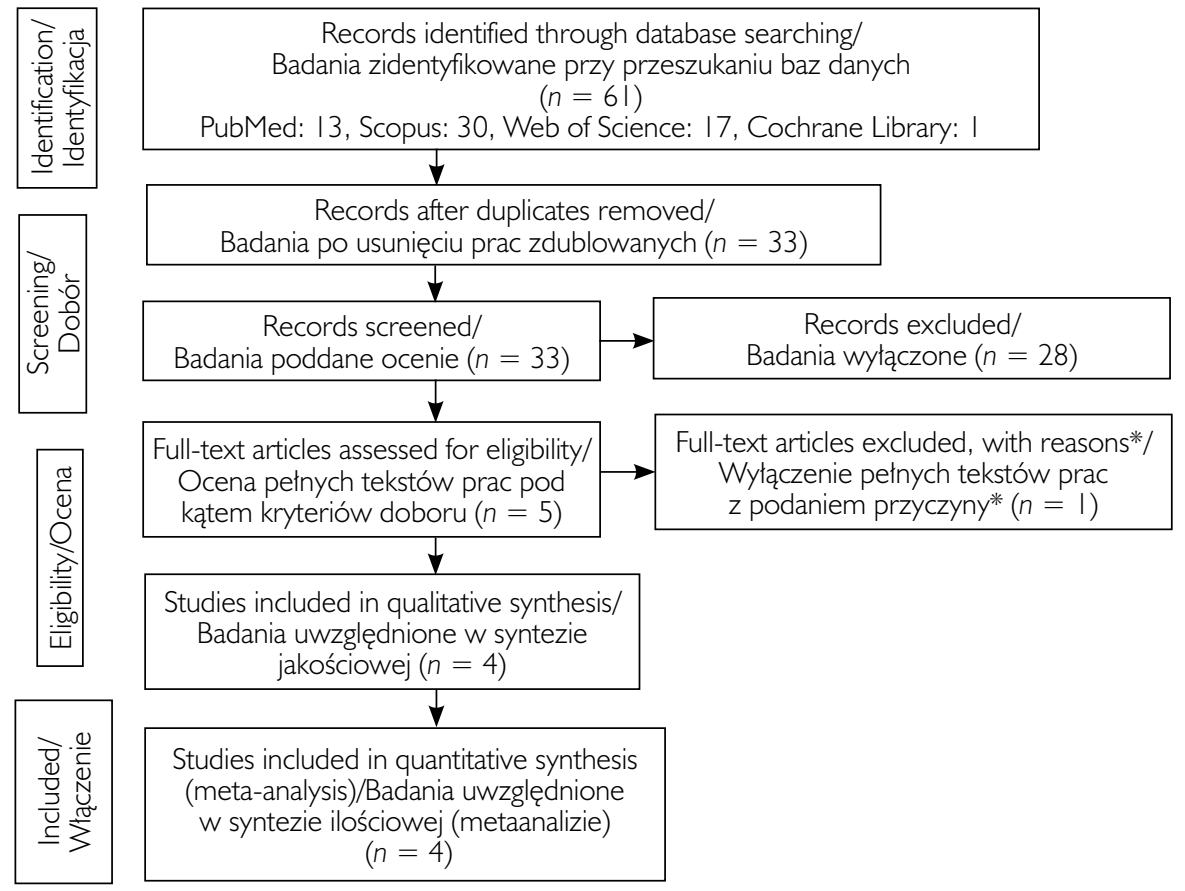

*I study reported CYPIA I mutations $\mathrm{W}$ I badaniu analizowano mutacje CYPIA I

Figure I. Flow-chart of the study

Rycina I. Schemat blokowy badania

studies; if $p<0.1$ or $I^{2}>50 \%$, there was statistically significant heterogeneity. If there was no significant heterogeneity, the fixed-effect model or the random effect model was applied to estimate the pooled ORs and $95 \%$ CI values. In addition, the $\chi^{2}$ test was used for the calculation of HWE in the control groups of each study. A subgroup analysis was done according to ethnicity. Also, CMA Software version 2.0 was used for a funnel plot analysis using both Egger's and Begg's tests; $p<0.05$ was showed a significant existence of publication bias.

\section{RESULTS}

Among 61 studies identified in the databases, four were included and analysed in quantitative analysis (meta-analysis) (fig. 1).

Some of the characteristics of the four studies included in the meta-analysis are shown in table 1 . Two studies [8, 13] were reported from Chinese, one [6] from Iranian, and one [14] from Polish populations. In all studies $[6,8,13,14]$, the genotype distribution of the polymorphism in controls corresponded with Hardy-Weinberg equilibrium (HWE). The meta-analysis included 598 acne patients and 528 controls.

The pooled OR of acne risk related to CYP17 (T-34C) polymorphism based on the allele, the homo-

\section{Analiza statystyczna}

Za pomocą oprogramowania Review Manager 5.3 dokonano analizy danych przy użyciu OR i 95\% CI pod kątem ewentualnej zależności między ryzykiem występowania trądziku a obecnością polimorfizmu (T-34C) CYP17 oraz wpływem tego polimorfizmu na nasilenie trądziku. Do oceny zależności wykorzystano pięć modeli genetycznych [19]. Za poziom istotności statystycznej przyjęto wartość $p<0,05$. Przy użyciu testu $Q$ Cochrana i testu statystycznego $I^{2}$ określono niejednorodność między badaniami. Przyjęto, że wartość $p<0,1$ lub $I^{2}>50 \%$ oznacza statystycznie istotny poziom niejednorodności. W przypadku braku statystycznie istotnej niejednorodności między badaniami do wyznaczenia łącznego OR i 95\% CI wykorzystano model z efektami stałymi, w pozostałych przypadkach - model z efektami losowymi. Przy wykorzystaniu testu $\chi^{2}$ obliczono równowagę HWE w grupach kontrolnych poszczególnych badań. Analizę podgrup przeprowadzono według kryterium pochodzenia etnicznego. Przy użyciu oprogramowania CMA Software (wersja 2.0) przeprowadzono analizę na podstawie wykresu lejkowego z wykorzystaniem testów Eggera i Begga, przyjmując, że wartość $p<0,05$ oznacza istotną tendencyjność publikacyjną. 
Table 2. Analysis of acne risk related to CYPI7 (T-34C) according to ethnicity

Tabela 2. Analiza zależności między ryzykiem wystąpienia trądziku a polimorfizmem (T-34C) CYPI7 według pochodzenia etnicznego

\begin{tabular}{|c|c|c|c|c|c|c|c|c|c|c|c|c|c|c|c|c|c|}
\hline \multirow{2}{*}{\multicolumn{2}{|c|}{ Paramater/Parametr }} & \multirow{2}{*}{$\begin{array}{l}\text { No. of } \\
\text { study/ } \\
\text { Numer } \\
\text { badania }\end{array}$} & \multicolumn{3}{|c|}{ C vs. T } & \multicolumn{3}{|c|}{ CC vs. TT } & \multicolumn{3}{|c|}{ TC vs. TT } & \multicolumn{3}{|c|}{$\mathrm{CC}+\mathrm{TC}$ vs. TT } & \multicolumn{3}{|c|}{$\mathrm{CC}$ vs. $\mathrm{TT}+\mathrm{TC}$} \\
\hline & & & $\begin{array}{c}(95 \% \\
\mathrm{Cl})\end{array}$ & $(\%)$ & & $\begin{array}{c}(95 \% \\
\mathrm{Cl})\end{array}$ & (\%) & & $\begin{array}{c}(95 \% \\
\mathrm{Cl})\end{array}$ & (\%) & & $\begin{array}{c}(95 \% \\
\mathrm{Cl})\end{array}$ & $(\%)$ & & $\begin{array}{c}(95 \% \\
\mathrm{Cl})\end{array}$ & $(\%)$ & \\
\hline \multicolumn{2}{|c|}{ Overall/Łącznie } & 4 & $\begin{array}{r}1.42 \\
(1.05- \\
1.93) \\
\end{array}$ & 57 & 0.07 & $\begin{array}{l}1.54 \\
(1.02- \\
2.33) \\
\end{array}$ & 0 & 0.59 & $\begin{array}{c}1.46 \\
(0.90- \\
2.34) \\
\end{array}$ & 61 & 0.05 & $\begin{array}{l}1.55 \\
(1.02- \\
2.37) \\
\end{array}$ & 56 & 0.08 & $\begin{array}{r}1.39 \\
(0.98- \\
1.98) \\
\end{array}$ & 0 & 0.68 \\
\hline \multirow[t]{2}{*}{$\begin{array}{l}\text { Ethnicity/ } \\
\text { Pochodzenie } \\
\text { etniczne }\end{array}$} & $\begin{array}{l}\text { Asian/ } \\
\text { Azjatyckie }\end{array}$ & 2 & $\begin{array}{c}1.34 \\
(1.05- \\
1.72) \\
\end{array}$ & 0 & 0.96 & $\begin{array}{c}1.76 \\
(1.08- \\
2.87) \\
\end{array}$ & 0 & 0.83 & $\begin{array}{c}1.26 \\
(0.82- \\
1.92) \\
\end{array}$ & 0 & 0.46 & $\begin{array}{c}1.42 \\
(0.95- \\
2.11) \\
\end{array}$ & 0 & 0.61 & $\begin{array}{c}1.52 \\
(1.02- \\
2.27) \\
\end{array}$ & 0 & 0.79 \\
\hline & $\begin{array}{l}\text { Caucasian/ } \\
\text { Kaukaskie }\end{array}$ & 2 & $\begin{array}{c}.55 \\
(0.7 \mid- \\
3.36)\end{array}$ & 85 & 0.01 & $\begin{array}{c}1.10 \\
(0.50- \\
2.40)\end{array}$ & - & - & $\begin{array}{c}1.70 \\
(0.69- \\
4.20) \\
\end{array}$ & 82 & 0.02 & $\begin{array}{c}1.70 \\
(0.69- \\
4.15)\end{array}$ & 83 & 0.02 & $\begin{array}{c}1.07 \\
(0.53- \\
2.16)\end{array}$ & - & - \\
\hline
\end{tabular}

Table 3. Analysis of acne risk related to CYPI7 (T-34C) in the patients with severe acne compared to those with mild + moderate acne Tabela 3. Analiza zależności między ryzykiem wystąpienia trądziku a polimorfizmem (T-34C) CYPI 7 u pacjentów z trądzikiem o nasileniu ciężkim w porównaniu z trądzikiem łagodnym oraz umiarkowanym

\begin{tabular}{|c|c|c|c|c|c|c|c|c|c|c|c|c|c|c|c|}
\hline \multirow{2}{*}{$\begin{array}{l}\text { References/ } \\
\text { Piśmiennictwo }\end{array}$} & \multicolumn{3}{|c|}{ C vs. T } & \multicolumn{3}{|c|}{ CC vs. TT } & \multicolumn{3}{|c|}{ TC vs. TT } & \multicolumn{3}{|c|}{$\mathrm{CC}+\mathrm{TC}$ vs. TT } & \multicolumn{3}{|c|}{ CC vs. TT + TC } \\
\hline & $\begin{array}{c}\text { OR } \\
(95 \% \\
\mathrm{Cl})\end{array}$ & $\begin{array}{l}{ }^{2} \\
(\%)\end{array}$ & $\mathrm{Ph}$ & $\begin{array}{c}\text { OR } \\
(95 \% \\
\mathrm{Cl})\end{array}$ & $\begin{array}{l}P^{2} \\
(\%)\end{array}$ & $\mathrm{Ph}$ & $\begin{array}{c}\text { OR } \\
(95 \% \\
\mathrm{Cl})\end{array}$ & $\begin{array}{l}l^{2} \\
(\%)\end{array}$ & $\mathrm{Ph}$ & $\begin{array}{c}\text { OR } \\
(95 \% \\
C l)\end{array}$ & $\begin{array}{l}l^{2} \\
(\%)\end{array}$ & $\mathrm{Ph}$ & $\begin{array}{c}\text { OR } \\
(95 \% \\
\mathrm{Cl})\end{array}$ & $\begin{array}{c}R^{2} \\
(\%)\end{array}$ & $\mathrm{Ph}$ \\
\hline$[8,14]$ & $\begin{array}{c}1.47 \\
(1.07- \\
2.02)\end{array}$ & 16 & 0.28 & $\begin{array}{c}2.79 \\
(1.24- \\
6.25)\end{array}$ & - & - & $\begin{array}{r}1.37 \\
(0.84- \\
2.22)\end{array}$ & 0 & 0.45 & $\begin{array}{l}1.51 \\
(0.95- \\
2.42)\end{array}$ & 25 & 0.25 & $\begin{array}{c}1.92 \\
(1.04- \\
3.55)\end{array}$ & - & - \\
\hline
\end{tabular}

zygote, the heterozygote, the dominant, and the recessive models are shown in figure 1 . The OR in analysis of $\mathrm{C}$ versus $\mathrm{T}$ in acne patients compared to the healthy controls was 1.42 (95\% CI: $1.05-1.93 ; p=0.02)$, in CC vs. TT it was 1.54 (95\% CI: 1.02-2.33; $p=0.04)$, in TC vs. TT it was 1.46 (95\% CI: 0.90-2.34; $p=0.12)$, in TC + CC vs. TT it was 1.55 (95\% CI: $1.02-2.37 ; p=0.04)$, and in CC vs. TT + TC it was 1.39 (95\% CI: 0.98-1.98; $p=0.06)$.

Five genetic models for the analysis of acne risk related to CYP17 (T-34C) according to patients' ethnicity are shown in table 2 . In the overall analysis, there was heterogeneity in the allele, the heterozygote, and the dominant, models. There was no acne risk related to CYP17 (T-34C) in any of the genetic models in Caucasian ethnicity $[6,14]$, whereas in Asian ethnicity [8, 13] there was acne risk related to CYP17 (T-34C) without heterogeneity in analyses of $\mathrm{C}$ vs. T, CC vs. TT, CC + TC vs. TT, and CC vs. TT + TC in acne patients compared to the healthy controls; OR was 1.34 (95\% CI: 1.05-1.72), 1.76 (95\% CI: 1.08-2.87), 1.42 (95\% CI: 0.95-2.11), and 1.52 (95\% CI: 1.02-2.27), respectively.

Two studies analysed acne risk related to CYP17 (T-34C) in patients with severe acne compared to mild and moderate acne (table 3 ). There was a significant risk without heterogeneity in analyses of $C$ versus T, CC vs. TT, and CC vs. TT + TC; OR was 1.47 (95\% CI: 1.07-2.02), 2.79 (95\% CI: 1.24-6.25), and 1.92 (95\% CI: 1.04-3.55), respectively.

\section{WYNIKI}

Spośród 61 badań wyszukanych w bazach danych wybrano 4, a następnie poddano je analizie ilościowej (metaanalizie) (ryc. 1).

Wybraną charakterystykę 4 badań uwzględnionych $\mathrm{w}$ metaanalizie przedstawiono w tabeli 1 . Dwa badania $[8,13]$ zostały przeprowadzone w populacji chińskiej, jedno [6] w irańskiej i jedno [14] w polskiej. We wszystkich badaniach $[6,8,13,14]$ rozkład genotypowy polimorfizmu w grupach kontrolnych był zgodny $\mathrm{z}$ równowagą Hardy'ego-Weinberga (HWE). Metaanaliza objęła łącznie 598 pacjentów z trądzikiem i 528 osób z grup kontrolnych.

Łączny iloraz szans (OR) ryzyka wystąpienia trądziku w powiązaniu z polimorfizmem (T-34C) CYP17 dla modelu alleli, modelu homozygot, modelu heterozygot, modelu dominującego i modelu recesywnego przedstawiono na rycinie 1. Wartości ilorazu szans (OR) $\mathrm{w}$ analizie $\mathrm{C}$ vs TT $\mathrm{u}$ chorych na trądzik w porównaniu z osobami zdrowymi z grup kontrolnych wyniosły 1,42 (95\% CI: 1,05-1,93; $p=0,02)$, CC vs TT 1,54 (95\% CI: 1,02$2,33 ; p=0,04)$, TC vs TT 1,46 (95\% CI: 0,90-2,34; $p=0,12)$, TC + CC vs TT 1,55 (95\% CI: 1,02-2,37; $p=0,04)$, a CC vs TT + TC 1,39 (95\% CI: 0,98-1,98; $p=0,06)$.

Pięć modeli genetycznych do analizy zależności między ryzykiem wystąpienia trądziku a polimorfizmem (T-34C) CYP17 według pochodzenia 


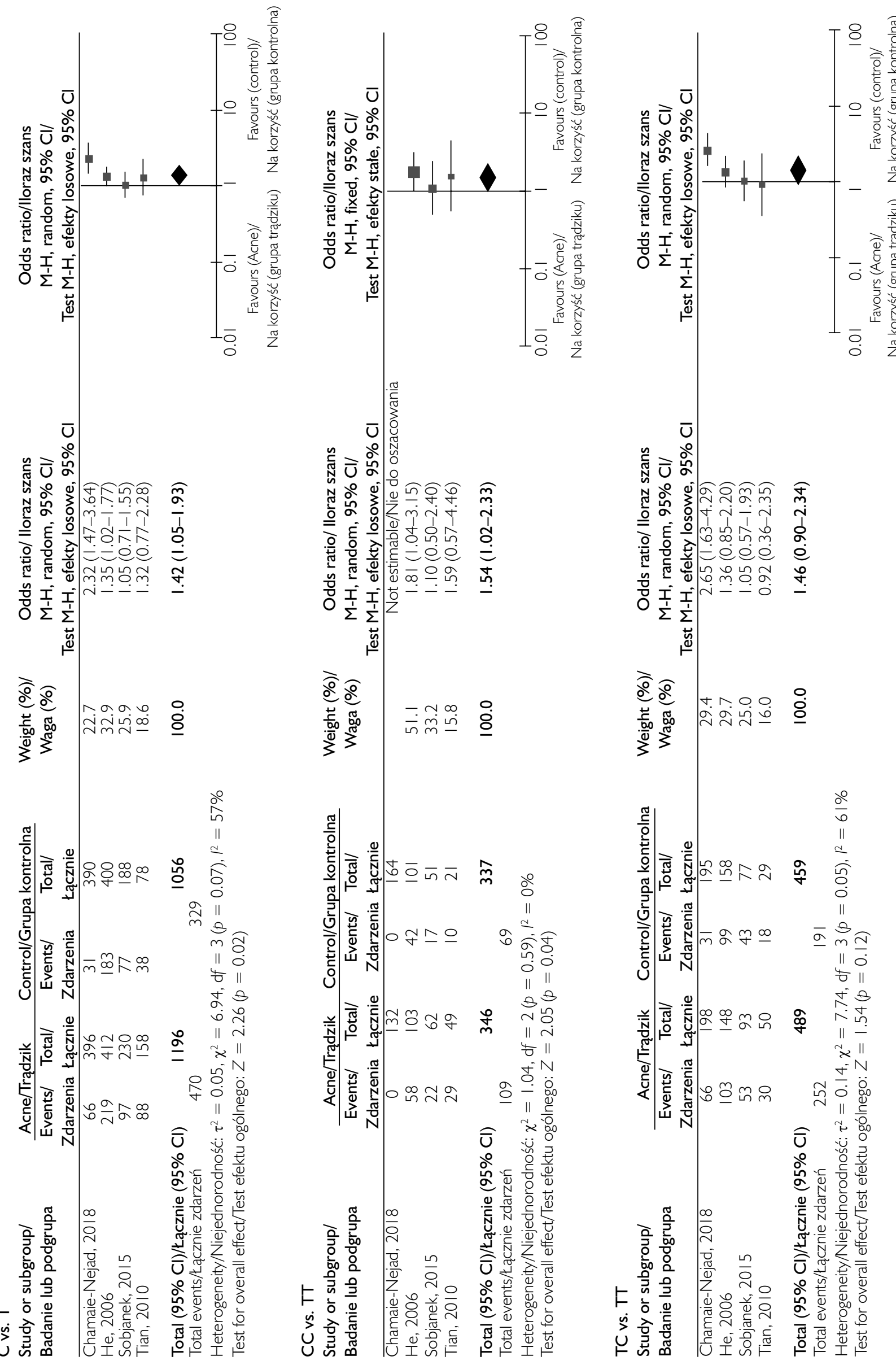



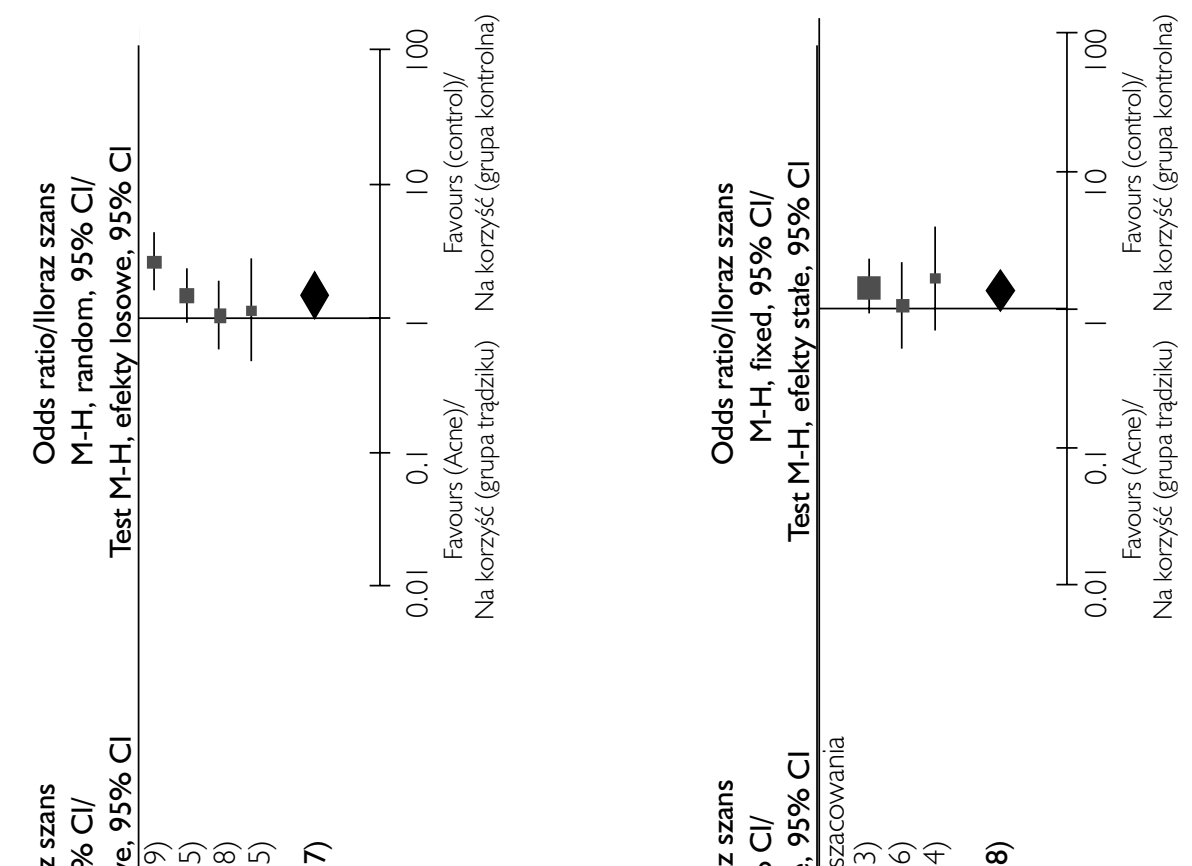

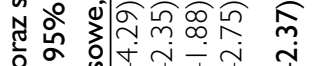

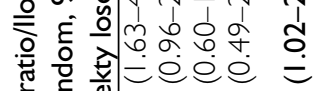

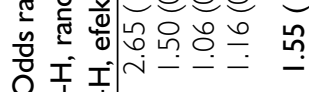

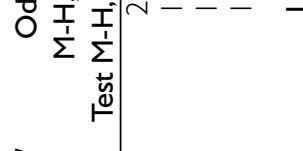

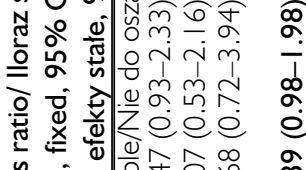

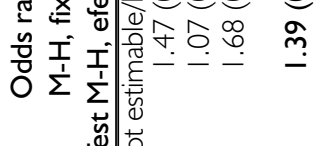

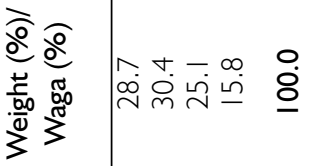

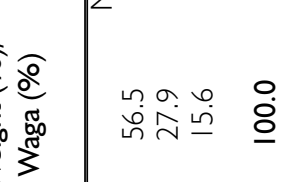

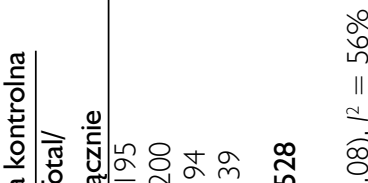

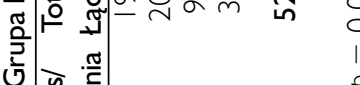

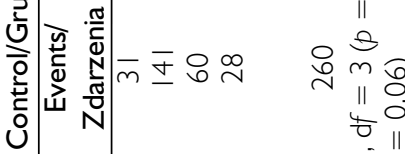

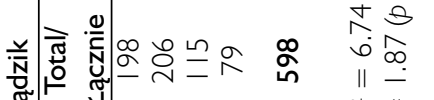

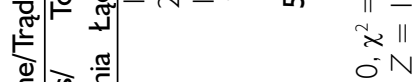

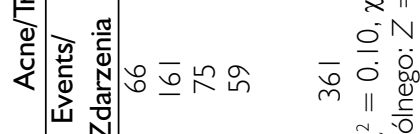

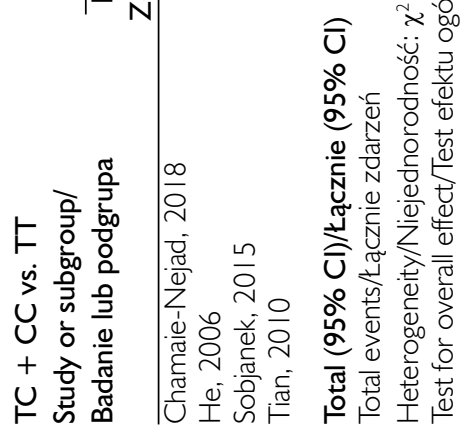

它范
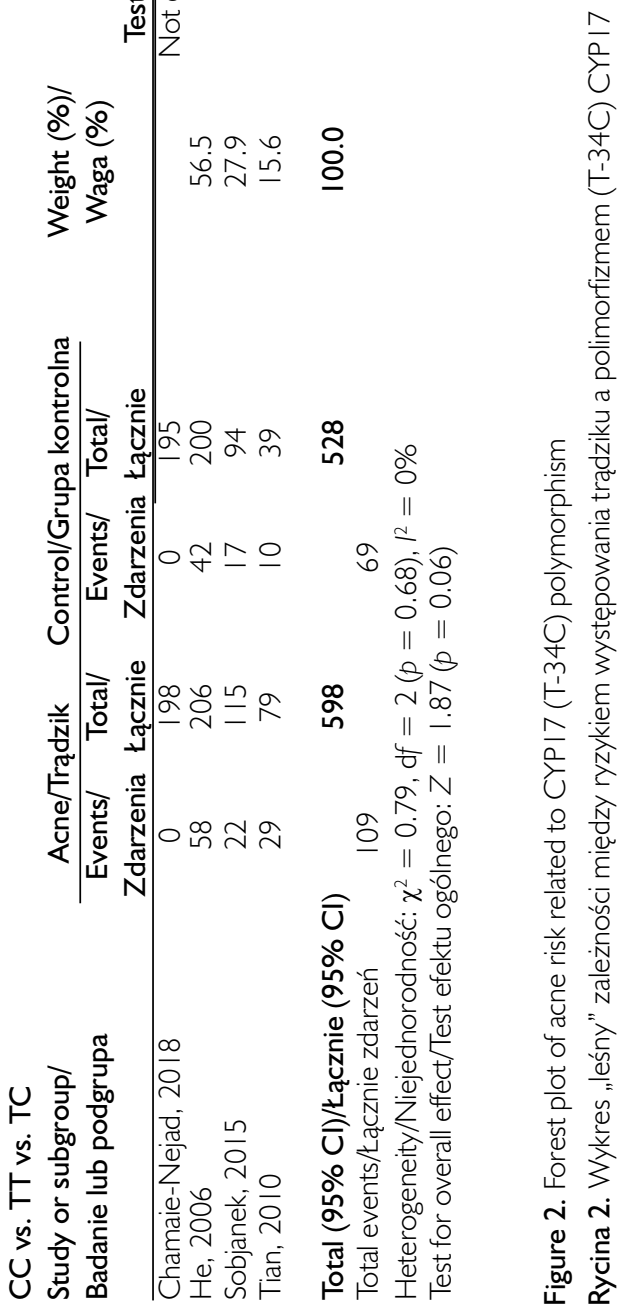

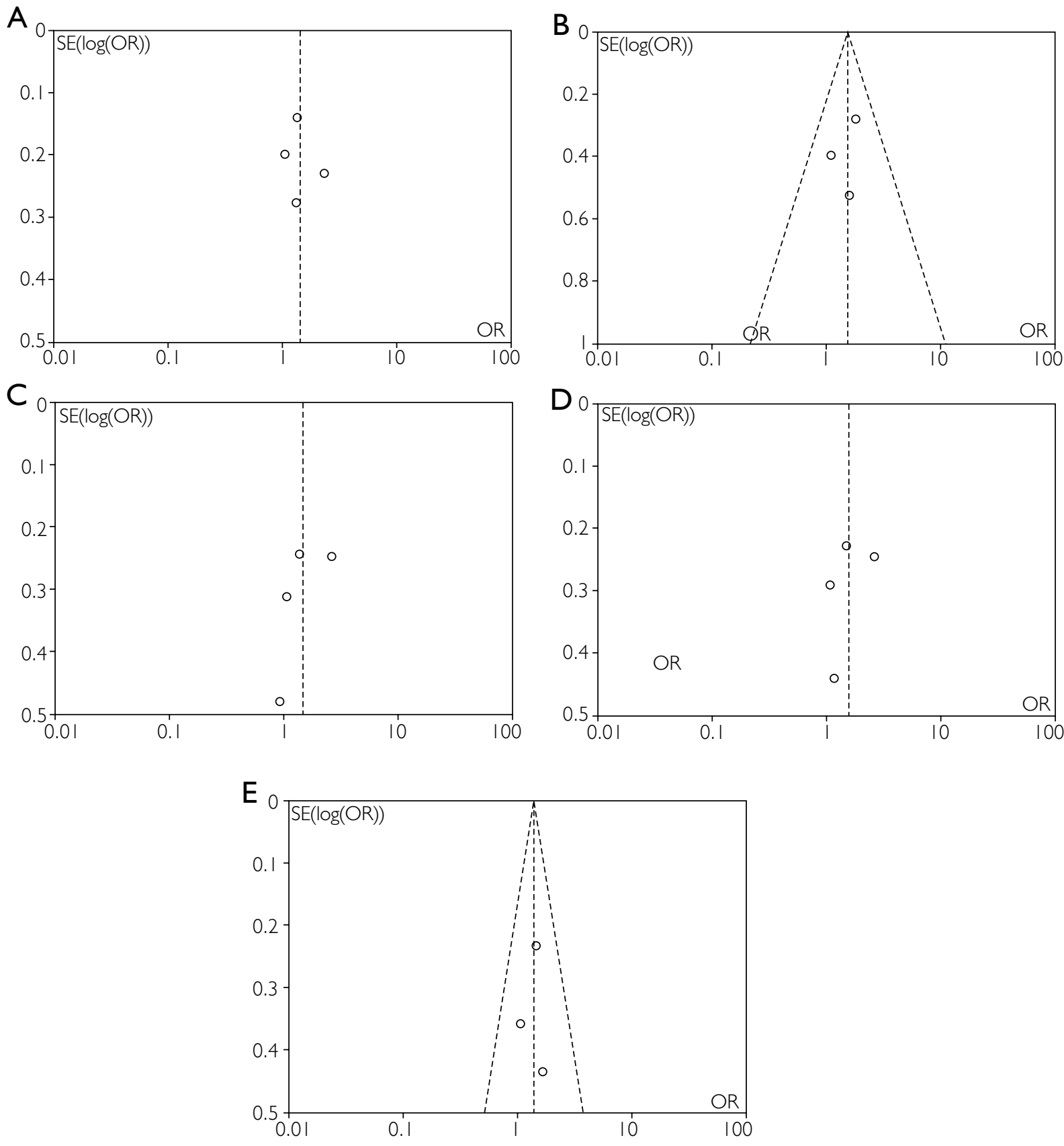

Figure 3. Funnel plot of acne risk related to CYPI7 (T-34C)

Rycina 3. Wykres lejkowy zależności między ryzykiem występowania trądziku a polimorfizmem (T-34C) CYP I7

\section{Publication bias}

The funnel plots of overall analysis based on the genetic models are shown in figure 3. Egger's and Begg's tests did not identify any publication bias among the analyses.

\section{DISCUSSION}

The present meta-analysis evaluated the CYP17 (T-34C) polymorphisms (rs743572) in acne vulgaris etnicznego pacjentów przedstawiono w tabeli 2. W analizie ogólnej niejednorodność stwierdzono w modelu alleli, modelu homozygot i modelu dominującym. Nie potwierdzono zależności między ryzykiem występowania trądziku a polimorfizmem (T-34C) CYP17 w żadnym z analizowanych modeli genetycznych u osób pochodzenia kaukaskiego [6, 14], natomiast u osób pochodzenia azjatyckiego [8, 13] wykazano ryzyko rozwoju trądziku związane z obecnością polimorfizmu (T-34C) CYP17, bez niejednorodności w analizach C vs T, CC vs TT, CC + 
patients compared with controls and showed that subjects carrying C allele or CC genotypes were at higher risk of developing acne in its severe form. The association between such a polymorphism and acne was first presented by He et al. in 2006 [8]. It is well known that the aetiology of acne vulgaris is multifactorial and correlated with both genetic and environmental factors [6]. CYP17 is a microsome enzyme and a potent oxidant to catalyse two distinct activities, 17a-hydroxylase and 17, 20-lyase, which are essential for the anabolism of adrenal and gonads steroids [20], especially in androgen production [21, 22]. When the androgen level increases, also the production of sebum and follicular keratosis rises and the acne development is promoted [8]. Indeed, androgens play a key role in the pathogenesis of acne, and anti-androgen therapy, in some patients, allows very successful treatment [23]. To date, in the literature no conclusive data are reported on the effect of CYP17 polymorphisms on $17 \alpha$-hydroxylase/17,20-lyase activity; however, this SNP has been extensively studied in several hormone-related neoplasms (i.e. prostate, breast, endometrial cancer) with controversial results $[11,12,16]$.

Interestingly, the allele variant $\mathrm{T} / \mathrm{C}$ at the $-34 \mathrm{bp}$ position (rs743572) is relative to the start codon located in the $5^{\prime}$-UTR promoter region of CYP17, a region strictly associated with gene expression. Other CYP17 SNPs (rs6162 and rs6163) are in strong linkage disequilibrium with rs743572, and they have been detected in patients with high levels of androgens, suggesting that such polymorphisms may influence the gene expression of sex hormones [24].

Out of four studies involved in the present metaanalysis, two studies $[8,13]$ performed among Asian populations showed the presence of $\mathrm{C}$ allele and CC genotype as significant risk factors in acne, whereas two other studies $[6,14]$ involving Caucasians did not show any risk factor related to the CYP17 polymorphism. In addition, the overall results of two studies $[8,14]$ reporting the correlation between SNPs and acne risk showed that there was a positive association between the presence of $\mathrm{C}$ allele and CC genotype and acne severity. The first study [8] compared the association between SNP and acne risk in females and males separately. In the male group affected by severe acne, the allele $C$ compared to $T$ allele and CC genotype showed a significantly increased risk of the disease compared with TT and TC genotypes, while no significant difference in genotype and allele distribution was reported in females. Accordingly, Tian et al. [13] reached similar results regarding female post-adolescent acne [8]. In addition, the study by Chamaie-Nejad et al. [14], including 198 acne patients (85.4\% females) and 195 healthy controls $(73.3 \%$ females), showed that the $\mathrm{C}$ allele and TC genotype
TC vs TT i CC vs TT + TC u pacjentów z trądzikiem $\mathrm{w}$ porównaniu z osobami zdrowymi z grup kontrolnych - wartości OR wyniosły odpowiednio: 1,34 (95\% CI: 1,05-1,72), 1,76 (95\% CI: 1,08-2,87), 1,42 (95\% CI: 0,95-2,11) oraz 1,52 (95\% CI: 1,02-2,27).

W dwóch badaniach analizowano ryzyko występowania trądziku $\mathrm{w}$ powiązaniu $\mathrm{z}$ polimorfizmem (T-34C) CYP17 u pacjentów z trądzikiem o nasileniu ciężkim w porównaniu $\mathrm{z}$ trądzikiem o nasileniu łagodnym i umiarkowanym (tab. 3). Stwierdzono istotne ryzyko bez niejednorodności $\mathrm{w}$ analizach $\mathrm{C}$ vs $\mathrm{T}$, CC vs TT oraz CC vs TT + TC, przy czym wartość OR wyniosła odpowiednio 1,47 (95\% CI: 1,07-2,02), 2,79 (95\% CI: 1,24-6,25) oraz 1,92 (95\% CI: 1,04-3,55).

\section{Tendencyjność publikacyjna}

Wykresy lejkowe analizy ogólnej opartej na modelach genetycznych przedstawiono na rycinie 3. Na podstawie testów Eggera i Begga nie stwierdzono tendencyjności publikacyjnej wśród analiz.

\section{OMÓWIENIE}

W przeprowadzonej metaanalizie oceniano obecność polimorfizmu (T-34C) CYP17 (rs743572) u chorych na trądzik pospolity w porównaniu z grupą kontrolną. Wykazano, że osoby z genotypami C lub CC są bardziej narażone na trądzik o ciężkim przebiegu. Zależność między badanym polimorfizmem a występowaniem trądziku została po raz pierwszy opisana w pracy He i wsp. z 2006 roku [8]. Wiadomo, że etiologia trądziku pospolitego jest wieloczynnikowa i powiązana z czynnikami zarówno genetycznymi, jak i środowiskowymi [6]. CYP17 jest enzymem zawartym w mikrosomach i silnym utleniaczem katalizującym aktywność zarówno 17 $\alpha$-hydroksylazy, jak i 17,20-liazy, które są niezbędne do anabolizmu steroidów nadnerczowych i gonadalnych [20]. Ma to istotne znaczenie zwłaszcza dla produkcji androgenów [21, 22]. Gdy stężenie androgenów wzrasta, nasila się również wytwarzanie sebum i rogowacenie mieszkowe, co sprzyja rozwojowi trądziku [8]. Androgeny odgrywają ważną rolę w patogenezie tej choroby, a leczenie przeciwandrogenowe daje bardzo dobre efekty u części pacjentów [23]. Dotychczas w piśmiennictwie nie przedstawiono spójnych danych na temat wpływu polimorfizmów CYP17 na aktywność $17 \alpha$-hydroksylazy/17,20-liazy, choć analizowany SNP był kompleksowo badany w kilku nowotworach hormonozależnych (tj. nowotworach gruczołu krokowego, piersi, raka trzonu macicy), a wyniki były niejednoznaczne $[11,12,16]$.

Ponadto wariant allela $\mathrm{T} / \mathrm{C} \mathrm{w}$ pozycji $-34 \mathrm{pz}$ (rs743572) jest związany z kodonem startowym zlokalizowanym $\mathrm{w}$ regionie promotora 5'-UTR CYP17, który wykazuje ścisłą zależność z ekspresją genów. 
were the main risk factors in acne. Therefore, further studies considering the role of gender in the association of the CYP17 polymorphism and acne risk are needed.

It has to be taken in account that, with regard to the studies included in the present meta-analysis, one study [8] did not report the age of the patients, while the other studies reported different age ranges (1343 years, age $>20$ years, and 26-42 years, respectively) $[6,13,14]$. Hence, age, in addition to gender, can have an impact on this association. Worthy of note, in the present meta-analysis two important limitations can be represented by the difference in age range and sex percentage between the studies; unfortunately, only a few studies have reported that they can be responsible for the heterogeneity in a number of analyses. On the contrary, no bias in the overall analysis and also in a subgroup analysis of Asian ethnicity was reported.

\section{CONCLUSIONS}

The results of the present meta-analysis showed that the presence of $C$ allele and $C C$ genotype of CYP17 (T-34C) SNP can represent risk factors for acne, mainly in Asian ethnicity. However, age and gender can act as two confounding factors and modify the association between CYP17 (T-34C) polymorphism and acne risk. Further studies are needed to examine these two factors in acne patients in order to obtain more accurate results.

\section{ACKNOWLEDGMENTS}

Research Council of Kermanshah University of Medical Sciences supported this work (Grant Number: 980758).

\section{CONFLICT OF INTEREST}

The authors declare no conflict of interest.
Inne SNP CYP17 (rs6162 i rs6163) znajdują się w silnej nierównowadze sprzężeń z rs743572, a ich wykrycie u pacjentów z dużymi stężeniami androgenów wskazuje, że takie polimorfizmy mogą wpływać na ekspresję genów kodujących ekspresję hormonów płciowych [24].

Spośród czterech badań uwzględnionych w metaanalizie dwa $[8,13]$ przeprowadzono u osób pochodzenia azjatyckiego. Wykazano w nich, że obecność allela $\mathrm{C}$ i genotypu CC stanowi istotny czynnik ryzyka w występowaniu trądziku. Z kolei w dwóch pozostałych badaniach $[6,14]$ przeprowadzonych u osób pochodzenia kaukaskiego nie stwierdzono żadnego czynnika ryzyka związanego z polimorfizmem CYP17. Ponadto ogólne wyniki uzyskane w dwóch badaniach $[8,14]$ analizujących zależność między SNP a ryzykiem rozwoju trądziku wykazały, że występuje dodatnia zależność między obecnością allela $\mathrm{C}$ i genotypu $\mathrm{CC}$ a stopniem nasilenia trądziku. W pierwszym badaniu [8] porównywano zależność między SNP a ryzykiem zachorowania na trądzik oddzielnie u kobiet i mężczyzn. U mężczyzn z trądzikiem o ciężkim nasileniu allel $\mathrm{C} \mathrm{w}$ porównaniu $\mathrm{z}$ allelem $\mathrm{T}$ i genotypem $\mathrm{CC}$ był powiązany z istotnie zwiększonym ryzykiem wystąpienia choroby $\mathrm{w}$ porównaniu $\mathrm{z}$ genotypami TT i TC. Z kolei u kobiet nie stwierdzono istotnych różnic pod względem rozkładu genotypów i alleli. Tian i wsp. [13] uzyskali podobne wyniki u kobiet z trądzikiem późnym [8]. W badaniu Chamaie-Nejad i wsp. [14] obejmującym 198 pacjentów z trądzikiem (85,4\% kobiet) i 195 zdrowych osób w grupie kontrolnej (73,3\% kobiet) wykazano, że głównymi czynnikami ryzyka w trądziku jest obecność allela $C$ i genotypu TC. Na tej podstawie należy uznać, że niezbędne są dalsze badania analizujące rolę płci w zależności między obecnością polimorfizmu CYP17 a ryzykiem wystąpienia trądziku.

Należy pamiętać, że w jednym z badań włączonych do metaanalizy [8] nie podano wieku pacjentów, natomiast pozostałe badania dotyczyły osób $\mathrm{w}$ różnych przedziałach wiekowych (odpowiednio 13-43 lata, > 20 lat i 26-42 lat) $[6,13,14]$. Oznacza to, że oprócz płci także wiek może mieć wpływ na badaną zależność. Należy podkreślić, że przedstawiona metaanaliza ma dwa istotne potencjalne ograniczenia - różnice w przedziale wiekowym i proporcji płci w poszczególnych badaniach. Niestety tylko w kilku pracach odnotowano, że czynniki te mogą odpowiadać za niejednorodność w szeregu analiz. Nie stwierdzono jednak obciążenia ani w analizie ogólnej, ani $\mathrm{w}$ analizie podgrupy osób pochodzenia azjatyckiego.

\section{WNIOSKI}

Wyniki przeprowadzonej metaanalizy wskazują, że obecność allela C oraz genotypu CC polimorfizmu 
SNP (T-34C) CYP17 może stanowić czynnik ryzyka występowania trądziku, głównie u osób pochodzenia azjatyckiego. Jednak wiek i płeć mogą być czynnikami zakłócającymi i wpływać modyfikująco na zależność pomiędzy polimorfizmem (T-34C) CYP17 a ryzykiem zachorowania na trądzik. Aby uzyskać bardziej szczegółowy obraz ewentualnych zależności, konieczne są dalsze badania analizujące te dwa czynniki u osób $\mathrm{z}$ tym schorzeniem skóry.

\section{PODZIĘKOWANIA}

Praca otrzymała wsparcie Research Council of Kermanshah University of Medical Sciences (numer grantu: 980758).

\section{KONFLIKT INTERESÓW}

Autorzy nie zgłaszają konfliktu interesów.

\section{References}

1. Melnik B.C.: Acne vulgaris: the metabolic syndrome of the pilosebaceous follicle. Clin Dermatol 2018, 36, 29-40.

2. Gollnick H.P., Bettoli V., Lambert J., Araviiskaia E., Binic I., Dessinioti C., et al.: A consensus-based practical and daily guide for the treatment of acne patients. J Eur Acad Dermatol Venereol 2016, 30, 1480-1490.

3. Bergler-Czop B., Brzezińska-Wcisło L.: Pro-inflammatory cytokines in patients with various kinds of acne treated with isotretinoin. Adv Dermatol Allergol 2014, 31, 21-28.

4. Ballanger F., Baudry P., N'Guyen J.M., Khammari A., Dréno B.: Heredity: a prognostic factor for acne. Dermatology 2006, 212, 145-149.

5. Goulden V., McGeown C.H., Cunliffe W.J.: The familial risk of adult acne: a comparison between first-degree relatives of affected and unaffected individuals. Br J Dermatol 1999, 141, 297-300.

6. Sobjanek M., Zabłotna M., Dobosz-Kawałko M., Michajłowski I., Mędrzycka-Dąbrowska W., Nowicki R.: Polymorphisms in the cytochrome P-450 (CYP) 1 A1 and 17 genes are not associated with acne vulgaris in the Polish population. Adv Dermatol Allergol 2015, 32, 323-326.

7. Sobjanek M., Sokołowska-Wojdyło M., Barańska-Rybak W., Nowicki R., Włodarkiewicz A.: Rola czynników hormonalnych w etiopatogenezie i terapii trądziku pospolitego. Adv Dermatol Allergol 2006, 23, 266-272.

8. He L., Yang Z., Yu H., Cheng B., Tang W., Dong Y., et al.: The relationship between CYP17 -34T/C polymorphism and acne in Chinese subjects revealed by sequencing. Dermatology 2006, 212, 338-342.

9. Paraskevaidis A., Drakoulis N., Roots I., Orfanos C.E., Zouboulis C.C.: Polymorphisms in the human cytochrome P-450 1 A1 gene (CYP1A1) as a factor for developing acne. Dermatology 1998, 196, 171-175.

10. Miller W.L.: Early steps in androgen biosynthesis: from cholesterol to DHEA. Baillières Clin Endocrinol Metab 1998, 12, 67-81.

11. Ambrosone C.B., Moysich K.B., Furberg H., Freudenheim J.L., Bowman E.D., Ahmed S., et al.: CYP17 genetic polymorphism, breast cancer, and breast cancer risk factors. Breast Cancer Res 2003, 5, R45-R51.

12. Sun J., Zhang H., Gao M., Tang Z., Guo D., Zhang X., et al.: Association between CYP17 T-34C rs743572 and breast cancer risk. Oncotarget 2017, 9, 4200-4213.

13. Tian L.M., Xie H.F., Yang T., Hu Y.H., Li J.: Correlation between CYP17 gene polymorphisms and female post adolescent acne in Han population in Hunan Province. Nan Fang Yi Ke Da Xue Xue Bao 2010, 30, 1590-1592, 1596.

14. Chamaie-Nejad F., Saeidi S., Najafi F., Ebrahimi A., Rahimi Z., Shakiba E., et al.: Association of the CYP17 MSP AI (T-34C) and CYP19 codon 39 (Trp/Arg) polymorphisms with susceptibility to acne vulgaris. Clin Exp Dermatol 2018, 43, 183-186.

15. Chace C., Pang D., Weng C., Temkin A., Lax S., Silverman W., et al.: Variants in CYP17 and CYP19 cytochrome P450 genes are associated with onset of Alzheimer's disease in women with down syndrome. J Alzheimers Dis 2012, 28, 601-612.

16. Cai L., Huang W., Chou K.C.: Prostate cancer with variants in CYP17 and UGT2B17 genes: a meta-analysis. Protein Pept Lett 2012, 19, 62-69.

17. Moher D., Liberati A., Tetzlaff J., Altman D.G.; PRISMA Group: Preferred reporting items for systematic reviews and metaanalyses: the PRISMA statement. PLoS Med 2009, 6, e1000097.

18. Wells G.A., Shea B., O'Connell D., Robertson J., Peterson J., Welch V., et al.: The Newcastle-Ottawa scale (NOS) for assessing the quality of non-randomised studies in meta-analyses. Ottawa: Ottawa Hospital Research Institute. 2011. http://www. ohri.ca/programs/clinical_epidemiology/oxford.asp. Accessed 12 Jan 2016. 
19. Lei S., Huang L., Liu Y., Xu L., Wang D., Yang L.: Association between polymorphisms of heat-shock protein 70 genes and noise-induced hearing loss: a meta-analysis. PLoS One 2017, 12, e0188539.

20. Liu Y., Yao Z.X., Papadopoulos V.: Cytochrome P450 17alpha hydroxylase/17,20 lyase (CYP17) function in cholesterol biosynthesis: identification of squalene monooxygenase (epoxidase) activity associated with CYP17 in Leydig cells. Mol Endocrinol 2005, 19, 1918-1931.

21. Liu Y., Yao Z.X., Bendavid C., Borgmeyer C., Han Z., Cavalli L.R., et al.: Haploinsufficiency of cytochrome P450 17alphahydroxylase/17,20 lyase (CYP17) causes infertility in male mice. Mol Endocrinol 2005, 19, 2380-2389.

22. Szabo K., Kemeny L.: Studying the genetic predisposing factors in the pathogenesis of acne vulgaris. Hum Immunol 2011, 72, 766-773.

23. Miller J.A., Wojnarowska F.T., Dowd P.M., Ashton R.E., O'Brien T.J., Griffiths W.A., et al.: Anti-androgen treatment in women with acne: a controlled trial. Br J Dermatol 1986, 114, 705-716.

24. Al-Rubae'I S.H.N., Sami Naji T., Turki K.M.: Common variation of the CYP17 gene in Iraqi women with endometriosis disease. Genomics Data 2017, 11, 55-59.

Received: 28.01 .2019

Accepted: 7.08.2019

Otrzymano: $28.01 .2019 \mathrm{r}$.

Zaakceptowano: 7.08.2019 r.

How to cite this article

Ramezani M., Zavattaro E., Sadeghi M.: Association of cytochrome P-45017 (T-34C) polymorphism and the risk of acne vulgaris: a meta-analysis. Dermatol Rev/Przegl Dermatol 2019, 106, 591-602. DOI: https://doi.org/10.5114/dr.2019.92732. 